\title{
KEPEMIMPINAN KH. IMAM ZARKASYI DI PONDOK MODERN DARUSSALAM GONTOR
}

\author{
Imroatul Fatihah \\ IAIN Syekh Nurjati Cirebon \\ iimfatihah@gmail.com
}

\begin{abstract}
Abstrak
Arikel ilmiah ini membuktikan bahwa kepemimpinan KH Imam Zarkasyi dalam memimpin PMDG mengedepankan keteladanan dan kedisiplinan. Keteladanan butuh kedisiplinan dan begitu pula sebaliknya. Kedisiplinan tanpa keteladanan merupakan omong kosong. Kepemimpinan KH. Imam Zarkasyi dilandasi filsafat hidup yang visioner melampaui zamannya dan keikhlasan hanya karena Allah azza wajalla. Sehingga ia memiliki pengaruh yang sangat kuat di ingatan, pikiran, dan hati sanubari yang paling dalam para santrinya. Kepemimpinannya tidak hanya sebatas menyentuh daya intelek namun juga meresap kepada mental, ruh, dan jiwa para santri. Model kepemimpinannya pun terus terestafetkan oleh para santri dan generasi penerusnya. Kajian ini bersifat kualitatif dengan riset kepustakaan dan analisis data heuristik, kritik sumber, interpretasi atau penafsiran, dan historiografi.
\end{abstract}

Kata Kunci: Kepemimpinan, KH Imam Zarkasyi, Gontor, Pesantren

\section{Pendahuluan}

KH. Imam Zarkasyi adalah salah satu pendiri Pondok Modern Darussalam Gontor (PMDG) bersama kedua kakaknya KH. Ahmad Sahal dan KH. Zanuddin Fannani. Ketiga pendiri PMDG kemudian biasa di panggil dengan sebutan "Trimurti". KH. Imam Zarkasyi tokoh pejuang dan pemikir serta cendekiawan Muslim yang ikut andil dalam pergerakan kemerdekaan Indonesia. Kontribusi besarnya yaitu membangun Sumber Daya Manusia (SDM) Indonesia. Perjuangan dan pemikiranya ia curahkan dalam dunia pendidikan dan karya-karyanya yang berupa tulisan (Sukarto, 1996).

Pembaharuan dan modernisasi lembaga pendidikan yang dibinanya ini dibuktikan dengan kiprah para santrisantri yang telah menamatkan pendidikan di PMDG. Para alumni yang tersebar di Indonesia mulai Sabang sampai Merauke. Bahkan, hingga mencapai negara tetangga di Asia Tenggara, seperti Malaysia, Thailand, Singapura, dan Filipina. Para alumninya PMDG bergerak di berbagai bidang sesuai dengan keterampilan yang dimilikinya.

Perjuangan dan pemikirannya, ia curahkan dalam memimpin dan mengelola PMDG. Gaya dan model kepemimpinannya sangat dipengaruhi oleh filsafat hidupnya yang modern, maju, dan progresif. Pemikirannya melampaui zamannya, sehingga lembaganya tetap eksis, suvive dan makin maju dari masa Penjajahan Belanda hingga era kontemporer. 


\section{Metode Penelitian}

Jenis penelitian ini adalah penelitian kualitatif dengan pendekatan pustaka (Libarari Reseach) kerena penelitian ini lebih kepada studi tokoh dan biografi maka desain penelitiannya melalui pendekatan sejarah. Penelitian sejarah begitu kompleks dengan peristiwa masa lalu, maka dalam melakukan analisis pengkajianya memerlukan alat bantu, baik metode, metodologi maupun teori. Metode penelitian sejarah adalah seperangkat kaidah yang membantu peneliti untuk mengumpulkan sumbersumber sejarah. Metode dalam penelitian sejarah membahas tentang penelitian sumber, kritik sumber, sintesis sampai kepada penyajian hasil penelitian. Adapun langkah-langkah analisis data kajian ini adalah heuristik, kritik sumber, interpretasi atau penafsiran, dan historiografi.

\section{Biografi KH Imam Zarkasyi}

KH. Imam Zarkasyi dilahirkan pada tanggal 21 Maret 1910 di Desa Gontor, Kecamatan Ponorogo, Kabupaten Madiun, Jawa Timur. KH. Imam Zarkasyi, Ahmad Sahal (19011977) dan Zainuddin Fananie (1908-1967) dan Imam Zarkasyi (1910-1985) tiga bersaudara dari tujuh bersaudara. Empat kakak tertuanya terdiri dari satu orang kakak laki-laki (anak pertama) dan tiga orang kakak perempuan. Pak Zar, demikian sapaan akrabnya, adalah putra bungsu dari tujuh bersaudara dari pasangan Kiai Santoso Anom Besari dengan Nyai Sudarmi.

KH. Imam Zarkasyi, mulai menimba ilmu di beberapa pesantren yang ada di daerah kelahirannya, seperti Pesantren Josari, Pesantren Joresan dan Pesantren Tegalsari. Kemudian melanjutkan studi di Sekolah Ongkoloro (1925), KH. Imam Zarkasyi melanjutkan studinya di Pondok Pesantren Jamsarem
Kota Solo. Pada waktu yang sama KH. Imam Zarkasyi juga belajar di Sekolah Mamba'ul Ulum. Kemudian masih di kota yang sama ia melanjutkan pendidikannya di Sekolah Arabiyah Adabiyah yang dipimpin oleh KH. Al-Hasyimi sampai tahun 1930. Selama belajar di sekolahsekolah tersebut (terutama Sekolah Arabiyah Adabiyah) ia sangat tertarik pelajaran bahasa Arab dan kemudian mendalaminya. Setelah menyelesaikan pendidikannya di Solo, Imam Zarkasyi meneruskan studinya ke Kweekschool di Padang Panjang, Sumatera Barat hingga tahun 1935.

Setelah tamat belajar di tempat itu, ia diminta oleh gurunya, Mahmud Yunus (pengarang Kamus bahasa Arab Indonesia) untuk menjadi direktur perguruan tersebut. Namun Pak Zar hanya bersedia selama 1 tahun. Kemudian ia kembali ke Gontor. Sebab, Gontor lebih memerlukan kehadirannya. Di samping itu, kakaknya KH. Ahmad Sahal melarangnya berlamalama di luar Gontor.

Sepulang dari Padang Panjang tahun 1936 ia memperkenalkan program pendidikan baru Kulliyatul Mu'allimin alIslamiyah (KMI) dimana ia sendiri sebagai direkturnya. Prinsip K.H. Imam Zarkasyi dalam dunia politik adalah seperti apa yang sering diucapkannya, "Politik saya adalah pendidikan". Maka, yang lebih penting adalah bagaimana kita membina orang orang yang menjadi pejabat negara tadi, agar mereka siap menjadi pewarna negara. Kesemuanya tentu tidak lari dari jalur pendidikan sebagaimana mediatornya, maka pendidikan itulah yang lebih penting dalam hidup berpolitik dan bernegara.

Dalam bidang pendidiakan, yang saya ketahui, Pak Zar berpendapat bahwa ilmu pengetahuan saja bagi seseorang tidak cukup, karena ilmu pengetahuan hanyalah sebagai penunjang suatu keberhasilan, yang mempunyai peran lebih penting adalah keterampilan dan kecerdikan.

Imroatul Fatihah Vol. 2 No.2 ISSN 2549-0877 
Karena, kedua hal inilah yang sangat mewarnai kehidupan seseorang di masyrakat luas. Maka tak perlu heran bila Pondok Modern Gontor banyak memberikan kegiatan-kegiatan ekstrakulikuler. Memang, hal demikianlah yang ternyata sangat dibutuhkan oleh santri, baik berupa keterampilan kerja maupun keterampilan jiwa yang berupa mental kerja. Bila terjadi dampak negatif setelah itu seperti mengantuk di kelas- itu tak lebih dari sebuah resiko kalau kita mementingkan pendidikan dari pada pengajaran, yang secara wajar sebenarnya mudah diatasi oleh diri pribadi santri sendiri.

Dasar-dasar berpikir di pesantren, selain yang terdapat di kelas-kelas, juga terdapat dalam buku kecil semacam Khutbah Iftitah (Khutbah perkenalan), Petunjuk Mengisi Kekosongan, serta etiket dan sebagainya. Ide-ide pokok, seperti tujuan pokok pendidikan bukanlah dimaksudkan untuk mencetak "pegawai" sangat ditekankan oleh Pak Zar. Berpikir Non-sektarian juga sangat dikedepankan dalam rangka menekankan dan menggarisbawahi perluanya "Berdiri di atas dan untuk semua golongan".

\section{Transformasi Pemikiran KH. Imam Zarkasyi}

Pendidikan memang merupakan kunci kemajuan. Semakin baik kualitas pendidikan yang diselenggarakan oleh suatu masyarakat atau bangsa, maka akan diikuti dengan semakin baiknya kualitas masyarakat atau bangsa tersebut. All of the problem that confront the muslim word today, so the educational problem is the most challengging. That future of the muslim world will depend upon the way it respons to this challenge," yakni dari sekian banyak permasalahan yang merupakan tantangan terhadap dunia Islam dewasa ini, maka masalah pendidikan merupakan masalah yang paling menantang. Masa depan dunia Islam tergantung kepada cara bagaimana dunia Islam menjawab dan memecahkan tantangan ini.

Sejarahnya pondok pesantren sebagai bentuk institusi pendidikan Islam tertua di Indonesia telah mengalami kemajuan ditandai adanya pembaharuan pemikiran pendidikan Islam. Salah satu pembaharuan pemikiran tersebut adalah pengembangan pemikiran pendidikan Islam, yang tidak hanya terfokus pada materi dalam disiplin ilmu agama saja tetapi juga ilmu pengetahuan umum sebagaimana yang dilakukan oleh pemikir pembaharu ilmu pendidikan Islam di Indonesia, yaitu Imam Zarkasyi, pendiri Pondok Modern Darussalam.

KH. Imam Zarkasyi identik dengan Pondok Modern Darussalam Gontor. Ialah yang membesarkan pondok sehingga namanya menjadi terkenal. Keberhasilan KH. Imam Zarkasyi dalam mengelola pondok pesantren modern Gontor tersebut karena pemikirannya yang modern tentang lembaga pendidikan. Dalam pandangan KH. Imam Zarkasyi hal ini paling penting dalam pesantren bukanlah pelajarannya semata-mata, melainkan jiwanya. Jiwa itulah yang yang akan memelihara kelangsungan hidup pesantren dan menentukan filsafat hidup para santrinya.

Upaya pembaharuan dalam memajukan pondok ini KH. Imam Zarkasyi menerapkan apa yang disebut dengan panca jiwa, yaitu lima program kerja pondok yang senantiasa memberikan arah dan panduan untuk mewujudkan usaha-usaha pengembangannya dan kemajuan pondok tersebut. Panca Jangka tersebut meliputi pendidikan. Konsep pembaharuan Imam Zarkasyi yang berkenaan dengan pendidikan Islam yang kemudian beliau kemas dalam sebuah kurikulum, adalah disiplin pelajaran Tafsir, Fiqih, Usul Fiqih yang biasa di ajarkan di pesantren tradisional. Imam Zarkasyi juga Imroatul Fatihah Vol. 2 No.2 ISSN 2549-0877 
menambahkan ke dalam kurikulum lembaga pendidikan yang di asuhnya itu pengetahuan umum, seperti; Ilmu Pengetahuan Alam, Ilmu Pasti, Ilmu Tata Negara, Ilmu Jiwa dan sebagainya. Selain itu ada mata pelajaran yang ditekankan dan harus menjadi karakteristik pendidikannya, yaitu Bahasa Arab dan Bahasa Inggris.

Transformasi dalam bahasa Inggris ialah transform yang berartikan merubah bentuk atau rupa, transformation merupakan perubahan bentuk atau penjelmaan. Pendidikan berada di tengahtengah masyarakat yang terus menerus mengalami perubahan. Perubahan pada masyarakat terjadi secara berkesinambungan dan berjalan relatif cepat. Perubahan yang terjadi pada masyarakat lebih cepat dari pada perubahan yang terjadi pada pendidikan, sehingga terjadi gap/kesenjangan, jurang pemisah yang cukup tajam antara masyarakat dan pendidikan. Upaya untuk mempersempit jurang pemisah tersebut, pendidikan harus melakukan perubahan dan pembaharauan. Transformasi pendidikan akan berjalan dengan baik dan tepat jika dilakukan secara komprehensif.

Transformasi pendidikan dimaknai sebagai proses perubahan secara terusmenerus menuju kemajuan. Kata "Kemajuan" ditandai dengan karakter, budaya, dan prestasi. Pendidikan Islam dikatakan maju jika mampu bersaing dengan sekolahan modern. Pada pertengahan tahun 1970-an, lembaga pendidikan Islam pada umumya relatif jauh tertinggal dari sekolah modern. Pada tahun 1980-an muncul beberapa lembaga pendidikan Islam yang mulai berkembang. Pada tahun 1990-an mulai banyak lembaga pendidikan Islam yang mengalami kemajuan. Kemudian pada tahun 2000-an sudah mulai banyak sekolah Islam yang mampu bersaing dengan sekolah negeri non-Islam.
Rekontruksi pendidikan Islam tidak bisa dipisahkan dengan kebangkitan gagasan dan program modernisme Islam. Kerangka dasar yang berada di balik modernisme Islam secara keseluruhan, baik modernisme pemikiran maupun kelembagaan Islam merupakan prasyarat bagi kebangkitan kaum muslim di masa modern. Oleh karena itu, pemikiran dan kelembagaan Islam termasuk pendidikan haruslah dimodernisasi, sederhananya direkontruksi sesuai dengan kerangka modernitas, mempertahankan pemikiran kelembagaan Islam "tradisional" hanya akan memperpanjang nestapa ketidakberdayaan kaum muslim dalam berhadapan dengan kemajuan modern.

Dalam sejarahnya pondok pesantren sebagai bentuk institusi pendidikan Islam tertua di Indonesia telah mengalami kemajuan ditandai adanya pembaharuan pemikiran pendidikan Islam. Salah satu pembaharuan pemikiran tersebut adalah pengembangan pemikiran pendidikan Islam, yang tidak hanya terfocus pada materi dalam disiplin ilmu agama saja tetapi juga Ilmu pengetahuan umum sebagaimana yang dilakukan oleh pemikir pembaharu ilmu pendidikan Islam di Indonesia.

KH. Imam Zarkasyi melihat bahwa pendidikan merupakan bagian terpenting bagi kehidupan dan sekaligus kemajuan umat Islam. Untuk itu sejumlah upaya untuk mengonsolidasikan dan pembaruan sistem pendidikan menjadi salah satu syarat mutlak bagi kemajuan umat Islam. Menurutnya, salah satu kelemahan pesantren di masa lalu adalah tidak adanya tujuan pendidikan yang dituangkan dalam tahapan-tahapan rencana kerja atau program. Pendidikan berjalan sekaan hanya mengikuti arus keahlian kiai.

Berkenaan dengan ini, KH. Imam Zarkasyi merumuskan tujuan pesantrennya sebagai berikut: "Yang jelas hanya satu saja, yaitu untuk menjadi orang, jadi Imroatul Fatihah Vol. 2 No.2 ISSN 2549-0877 
masih bersifat umum dan belum menjurus, belum calon doktor, belum calon kusir,belum calon apa-apa. Katakanlah calon manusia. Manusia itu apa kerjanya?. Dari pendidikan yang kami berikan itu mereka akan tahu nanti di masyarakat apa yang akan dikerjakan. jadi persiapan untuk masuk masyarakat dan bukan untuk perguruan Tinggi. Maka dari itu, kami namakan pendidikannya, pendidikan kemasyarakatan, dan itu yang kami utamakan." Pembaharuan pendidikan pesantren yang dilakukan KH. Imam Zarkasyi juga didasarkan pada sejumlah kelemahan pondok pesantren tradisional pada saat itu. Sehingga untuk mengatasi berbagai kelemhan pondok pesantren tersebut, KH. Imam Zarkasyi terpanggil untuk menekankan tujuan pendidikan yang diarahkan (Nata, 2004: 204-205).

Salah satu gerakan modernisasi dunia Islam khususnya di Indonesia adalah Pondok Gontor. Pondok Modern Darussalam Gontor yang biasa disingkat PMDG. Gagasan yang melatarbelakangi pembentukan PMDG adalah kesadaran bahwa perlu dilakukan modernisasi sistem dan kelembagaan pendidikan Islam; tidak mengadopsi sistem dan kelembagaan pendidikan modern ala Belanda, melainkan dengan modernisasi sistem dan kelembagaan Islam indigenous, yaitu 'pesantren' (Madjid, 1997).

Pendirian Pondok Modern Gontor terinspirasi dari gagasan modern Sumatra Thawalib dan 'Normal Islam School' di Sumatra Barat. Hal itu tak lain karena KH. Imam Zarkasyi, salah satu pendiri Pondok Modern Darussalam Gontor, pernah menyelesaikan studinya disana. Namun, ada perubahan besar yang terjadi di Gontor yaitu penerapan sistem pengajaran modern 'al-Tariqah al-Haditsah' (Pondok Modern Darussalam Gontor, 1996: 51).

Perlu digarisbawahi bahwa apa yang ilakukan KH. Imam Zarkasyi bukanlah sepenuhnya menfotokopi ide dan konsep Normal Islam dan Sumatra Thawalib. Pengaruh gurunya, Al-Hasyimiseorang ulama, tokoh politik dan sastrawan dari Tunisia yang diasingkan oleh pemerintah Prancis i wilayah penjajahan Belanda-ketika ia belajar di Madrasah Arabiyah Islamiyah di Solo, ikut berperan mendesain perubahan pesantren yang sebelumnya dikelola oleh sang kakak, KH. Ahmad Sahal dan KH. Zainudin Fnnanie, sehingga tampak perbedaan mendasarnya.

Perbedaanya juga seperti apa yang dikemukakan oleh Lance Castles bahwa Gontor sngat mengecam keras sistem sekolah umum yang berasal dari kolonial, yang mana peserta didik terlalu banyak diarahkan bila tidak mau dikatakan tujuan utamanya pada pencetakan pegawai tanpa menanamkan cinta belajar. Perbeaan lainya, meminjam ungkapan mantan Mentri Agama, Mukti Ali (almarhum), jika al-Zarnuji lebih banyak menekankan kepada ilmu agama, maka Pak Zar menekankan kepada ilmu umum dan ilmu agama.

Pembaharuan aspek kelembagaan di Gontor dimulai dengan pewakafan Pondok Modern Darussalam Gontor kepada lembaga yang disebut Badan Wakaf Pondok Modern Gontor. Ikrar pewakafan ini telah dinyatakan di muka umum oleh ketiga pendiri pondok tersebut. Dengan ditandatanganinya peagam penyerahan wakaf itu, maka Pondok Modern Darussalam Gontor tidak lagi menjadi milik pribadi atau perseorangan sebagaimana umumnya dijumpai di lembaga tradisional. Dengan cara demikian, secara kelembagaan Pondok Modern Gontor menjadi milik ummat Islam, dan semua ummat Islam bertanggung jawab atas segala urusanurusannya (ihsan, 2004: 23).

Lembaga badan wakaf ini selanjutnya menjadi badan tertinggi di Pondok Modern Darussalam Gontor. Badan inilah yang bertanggung jawab Imroatul Fatihah Vol. 2 No.2 ISSN 2549-0877 
mengangkat kyai untuk masa jabatan lima tahun kedepan. Dengan demikian, kyai bertindak sebagai mandataris dan bertanggung jawab kepada badan wakaf. Untuk itu, Badan Wakaf memiliki lima program yang berkenaan dengan bidang pendidikan dan pengajaran, peralatan dan pergedungan, pewakafan dan sumber dana, kaderisasi serta kesejahteraan yang semuanya dirangkum dalam program Panca Jangka Pondok Modern Darussalam Gontor (Zarkasyi, 2005: 85-91).

Dengan struktur kepengurusan yang demikian, maka kyai dan keluarga tidak punya hak material apapun dari Pondok Gontor. Kyai dan guru-guru juga tiak mengurusi uang dari para santri, sehingga mereka tidak pernah membedakan antara santri yang kaya dan yang berkecukupan. Urusan keuangan menjadi tanggung jawab petugas kantor tata usaha yang terdiri dari beberapa santri senior dan guru yang secara periodik bisa diganti. Dengan demikian, pengaturan jalanya organisasi pendidikan menjadi dinamis, terbuka dan obyektif (Majalah Gontor, Februari 2014: 30).

KH. Imam Zarkasyi menegaskan pendidikan merupakan bagian terpenting bagi kehidupan dan sekaligus amat menentukan bagi kemajuan umat Islam. Sehingga, sejumlah upaya untuk pembaruan sistem pendidikan menjadi salah satu syarat mutlak bagi kemajuan umat Islam. Salah satu problem pesantren di masa lalu baginya adalah tidak adanya tujuan pendidikan yang jelas. Maksudnya, tujuan yang dapat dituangkan dalam tahapan-tahapan rencana kerja atau program. Pendidikan berjalan hanya mengikuti perkembangan alamiah masing-masing pesantren, dan tidak memiliki tujuan yang spesifik. Untuk itu, ia menawarkan tujuan pendidikan pesantren sebagaimana dalam ungkapan berikut.
"Yang jelas satu saja, yaitu untuk menjadi orang. Jadi masih bersifat umum dan belum menjurus, belum calon doktor, belum calon kusir, belum calon apa-apa. Katakanlah calon manusia. Manusia itu apa kerjanya? Dari pendidikan yang kami berikan itu mereka akan tahu nanti di masyarakat apa yang akan dikerjakan. Jadi persiapan untuk masuk masyarakat dan bukan untuk perguruan tinggi. Maka dari itu, kami namakan pendidikannya, pendidikan kemasyarakatan, dan itu yang kami utamakan” (Abuddin Nata, 2005: 207).

Setelah menyinggung tujuan pendidikan pesantren, Zarkasyi berusaha memperbaharui kurikulum pendidikan pesantren berdasarkan tujuan tersebut. Di Pondok Pesantren Modern Gontor Ponorogo ia menggagas dan menerapkan kurikulum yang biasa disebut $100 \%$ umum dan $100 \%$ agama. Di samping mengajarkan ilmu-ilmu keislaman seperti akidah, tafsir, hadis, fiqih, dan ushul fiqih yang biasa diajarkan di pesantren tradisional, Imam Zarkasyi menambahkan pengetahuan umum, seperti ilmu alam, ilmu hayat, ilmu pasti (berhitung, aljabar dan ilmu ukur), sejarah, tata negara, ilmu bumi, ilmu pendidikan, dan ilmu jiwa. Selain itu ada pula mata pelajaran yang amat ditekankan dan harus menjadi karakteristik lembaga pendidikannya itu, yaitu pelajaran bahasa Arab dan bahasa Inggris (Steenbrink, 1994).

Pelajaran bahasa Arab lebih ditekankan pada penguasaan kosa kata dan praktik, sehingga para santri kelas satu sudah diajarkan mengarang dalam bahasa Arab dengan perbendaharaan kosa kata yang dimilikinya. Pelajaran ilmu alat, yaitu nahwu dan sharraf diberikan kepada santri saat menginjak kelas II, yaitu ketika mereka sudah agak lancar berbicara dan memahami struktur kalimat. Bahkan pelajaran Balaghah dan Adab al- Lughah baru diajarkan pada saat santri menginjak

Imroatul Fatihah Vol. 2 No.2 ISSN 2549-0877 
kelas V. Hampir seluruh mata pelajaran diajarkan menggunakan pengantar bahasa Arab. Sementara pembelajaran bahasa Arab yang biasanya diajarkan menggunakan metode terjemah kini dipakai metode langsung, di mana bahasa dipakai alat komunikasi sehari-hari.

Kemudian, dalam upaya mendukung tercapainya moralitas dan kepribadian tersebut, kepada para santri diberikan juga pendidikan kemasyarakatan dan sosial yang dapat mereka gunakan untuk melangsungkan kehidupan sosial ekonominya. Untuk itu kepada para santri diberikan latihan praktis dalam mengamati dan melakukan sesuatu yang ia perkirakan akan dihadapinya dalam hidupnya kelak di masyarakat. Segala sesuatu diorganisir sedemikian rupa untuk memberikan gambaran realistik kepada santri tentang kehidupan dalam masyarakat. Para santri dilatih untuk mengembangkan cinta kasih yang mendahulukan kesejahteraan bersama daripada kesejahteraan pribadi, kesadaran pengorbanan yang diabadikan demi kesejahteraan masyarakat, khususnya umat Islam.

Selain itu juga, di Pondok Modern Darussalam Gontor diajarkan pelajaran ekstra seperti etiket atau tata krama yang berupa kesopanan lahir dan kesopanan batin. Kesopanan lahir termasuk gerakgerik, tingkah laku, bahkan pakaian, sedangkan kesopanan batin adalah menyangkut akhlak dan jiwa. Khusus untuk menopang kelangsungan hidup para santri dalam bidang ekonomi, diberikan pula pelajaran keterampilan seperti mencetak, mengetik, kerajinan tangan (dekorasi, letter, janur), dan sebagainya.

Materi dan kurikulum pondok modern Gontor pada dasarnya adalah totalitas dari kehidupan pondok itu sendiri, yang tidak bisa dipisah-pisahkan satu dengan yang lainnya. Tidak ada perbedaan antara pengetahuan agama dan pengetahuan umum. Semua siswa mendapatkan dua pengetahuan tersebut sekaligus sesuai dengan tingkatan kelas mereka masing-masing. KH. Imam Zarkasyi memiliki konsep keseimbangan antara ilmu umum dan ilmu agama yang harus diajarkan dalam proses pendidikan dengan menekankan penanaman jiwa keikhlasan, jiwa kesederhanaan, jiwa kemandirian, jiwa ukhuwah islamiyah dan jiwa bebas dalam setiap pengusaan mata pelajaran.

Kurikulum yang diterapkan Imam Zarkasyi di Pondok Pesantren Gontor adalah $100 \%$ umum dan $100 \%$ agama. Disamping pelajaran tafsir, hadist, fiqih, ushul fiqih, yang biasa diajarkan di pesantren tradisional. Imam Zarkasyi juga menambahkan ke dalam kurikulum lembaga pendidikan yang diasuhnya itu pengetahuan umum, seperti ilmu alam, ilmu hayat, ilmu pasti, sejarah, tata negara, ilmu bumi, ilmu pendidikan, ilmu jiwa dan sebagainya. Selain itu ada pula mata pelajaran yang amat ditekankan dan harus menjadi karakteristik lembaga pendidikan itu, yaitu pelajaran bahasa inggris dan bahasa arab. Pelajaran bahasa arab lebih ditekankan pada penguasaan kosa kata, sehingga para santri kelas satu sudah diajarkan mengarang dalam bahasa arab dengan perbendaharaan kosa kata yang dimilikinya.

Sejak Trimurti hingga kini selalu berusaha menanamkan rasa cinta para santrinya terhadap bahasa Arab dan bahasa Inggris, karena keduanya merupakan kunci yang penting dan menentukan dalam mewujudkan kebangkitan Islam. Dengan bahasa Arab dapat diciptakan millieu Qurani, dan dengan bahasa Inggris dapat dikejar kemajuan jaman dan ilmu pengetahuan. Untuk mewujudkan lingkungan itu dibentuklah Bagian Penggerak Bahasa yang bertujuan mengelola dan menjaga serta mengembangkan citra bahasa yang 
telah ada. Pendeknya Pondok Modern Darussalam Gontor Ponorogo make every effort to try it's both Arabic and English, as the key to religion and science.

Khusus pengajaran bahasa Arab ini ditempuh dengan metode langsung yang diarahkan kepenguasaan bahasa secara aktif dengan cara memperbanyak latihan (drill), baik lisan maupun tulisan. Pengajaran bahasa Arab mengacu kepada prinsip pengajaran bahasa sebagai bahasa ibu, bukan sebagai bahasa asing. Oleh karena itu, santri tidak langsung mendapat pelajaran atau pengajian Kitab Kuning sebagaimana layaknya dilaksankan di pondok pesantren. Para santri terlebih dahulu harus dapat berbicara dan menulis dalam bahasa Arab, maka dengan sendirinya ia mampu membaca berbagai kitab-kitab dalam bahasa Arab, termasuk membaca Kitab Kuning (Praja, 1990: 206).

Para siswa diberikan latihan praktis dalam mengamati dan melakukan sesuatu yang ia perkirakan akan dihadapinya dalam hidupnya kelak di masyarakat. Segala sesuatu diorganisasi sedemikian rupa untuk memberikan gambaran realistik kepada siswa tentang kehidupan dalam masyarakat. Para siswa dilatih untuk mengembangkan cinta kasih yang mendahulukan kesejahteraan bersama daripada kesejahteraan pribadi, kesadaran pengorbanan yang diabadikan demi kesejahteraan masyarakat, khususnya umat Islam (Ziemek, 1986: 159). Sejalan dengan itu, maka di PMDG diajarkan pelajaran ekstra seperti etiket atau tatakrama yang berupa kesopanan lahir dan kesopanan batin. Kesopanan batin menyangkut akhlak dan jiwa, sedangkan kesopanan lahir termasuk gerak-gerik, tingkah laku, bahkan pakaian (Ali, 1991: 53). Oleh sebab itu, siswa sudah diberikan ilmu yang bisa diamalkan dalam kehidupan sehari-hari yang bisa memberikan petunjuk kearah yang lebih baik dalam kehidupan.
PMDG adalah salah satu organisasi pengelola keagamaan, khususnya bidang pendidikan. Demi kepentingan pendidikan dan pengajaran Islam, KH. Imam Zarkasyi dan dua saudaranya telah mewakafkan Pondok Pesantren Gontor Kepada sebuah lembaga yang disebut Badan Wakaf Pondok Modern Gontor. Ikrar pewakafan ini telah dinyatakan di muka umum oleh ketiga pendiri pondok tersebut, dengan ditandatanganinya Piagam Penyerahan Wakaf itu, maka Pondok Modern Gontor tidak lagi menjadi milik pribadi atau perorangan sebagaimana yang umumnya dijumpai dalam lembaga pendidikan pesanteren tradisional. Dengan cara demikian, secara kelembagaan pondok Modern Gontor menjadi milik umat Islam, dan semua umat Islam bertanggung jawab atasnya (Ihsan, 2004: 23).

Dalam Pondok Modern Gontor lembaga badan wakaf tersebut selanjutnya menjadi lembaga tertinggi dalam organisasi balai pendidikan Pondok Modern Gontor. Lembaga inilah yang menjadi badan legislatif yang bertanggung jawab atas pelaksanaan dan perkembangan pendidikan dan pengajaran di Pondok Modern. Ia juga bertanggung jawab mengangkat kyai untuk masa jabatan lima tahun (majalah Gontor, Februari 2014: 30). Dengan demikian, kyai bertindak sebagai mandataris dan bertanggung jawab kepada Badan Wakaf. Kyai atau pimpinan pondok merupakan sebuah badan eksekutif yang yang dipilih oleh badan wakaf setiap lima tahun sekali. Pimpinan Pondok Modern Gontor membawahi beberapa lembaga, yaitu 1) Kuliyat Al-mu'alimin Al-Islamiah (KMI), 2) Institut Studi Islam Darussalam (ISID), 3) Pengasuhan santri, 4) Yayasan pemeliharaan dan Perluasan Wakaf Pondok, dan 5) Ikatan Keluarga Pondok Modern (Susanto, 2009: 145).

Disamping kelima lembaga ini, terdapat tiga lembaga lain yang juga bertanggung jawab langsung kepada

Imroatul Fatihah Vol. 2 No.2 ISSN 2549-0877 
pimpinan pondok tetapi posisinya tidak sejajar dengan kelima lembaga di atas, yaitu Pusat latihan Manajemen dan Pengembangan Masyarakat, bagian pembangunan dan bagian koperasi Pondok Pesantren. Dengan struktur pengurusan yang demikian, maka kyai dan keluarga tidak punya hak material apa pun dari gontor. Kyai dan guru-guru juga tidak mengurusi uang dari para santri, sehingga mereka tidak pernah membedakan antara santri yang kaya dengan santri yang kurang mampu. Urusan keuangan menjadi tanggung jawab petugas kantor tata usaha yang terdiri dari beberapa orang santri senior dan guru yang secara periodik bisa diganti. Dengan demikian, pengaturan jalannya organisasi pendidikan menjafi dinamis, terbuka dan obyektif (Majalah Gontor, Juni 2014: 30).

Pembaharuan yang dilakukan oleh KH. Imam Zarkasyi berkenaan dengan pola fikir dan kebebasan pesantren ini diterapkan melalui pembiasaan, keteladanan dan pengondisian lingkungan. KH. Imam Zarkasyi menekankan proses pembelajarannya kepada mental skill atau keterampilan mental bukan job skill atau keterampilan kerja. Mental skill ini mengarahkan santrinya kepada penanaman jiwa, bebas, merdeka, berkepribadian, dan berkeyakinan hidup. Dengan keterampilan mental ini diharapkan nantinya santri tidak menjadi penganggur, berbudi tinggi, dan mempunyai harapan hidup lebih baik.

Setelah keluar dari pondok pesantren, santri diharapkan mampu membuat pekerjaan sendiri dengan bekal keterampilan yang sudah didapatkan selama belajar di pondok. Yang dimaksud dengan pola fikir bebas dan merdeka disini adalah kebebasan yang berada dalam garisgaris disiplin yang positif, dengan penuh tanggung jawab, baik dalam kehidupan pondok maupun di masyarakat. Kebebasan ini juga menghendaki santri yang memiliki jiwa berdiri di atas kaki sendiri atau berdikari, santri bebas untuk menentukan masa depannya, memiliki jiwa keihklasan dan jiwa kesederhanaan dalam hidup.

Selanjutnya untuk mewujudkan kebebasan dan kemandirian tersebut, di Gontor para santri diberikan kebebasan memilih pilihan-pilihan mata pelajaran yang ada. Dalam pelajaran hukum Islam misalnya, kitab yang diajarkan adalah Bidayah al-Mujtabid karya Ulama besar Ibn Rusyd yang hidup pada masa abad ke12. Selanjutnya kemandirian pondok pesantren Gontor terlihat dari adanya kebebasan para santri yang bebas menentukan jalan hidupnya kelak. Imam Zarkasyi sering mengatakan bahwa Gontor tidak mencetak pegawai, tetaepi mencetak majikan untuk dirinya sendiri. Demikianlah sebagian kecil dari contoh pola dan siakp yang dikembangkan oleh Pondok Pesantren Gontor dalam menghadapi perubahan zaman. Sikap seperti ini terus dipertahankan sampai sekarang.

Dengan demikian, pemikiran Imam Zarkasyi tentang pentingnya ilmu pendidikan Islam yang mampu menumbuhkan dan menekankan pada nilai-nilai luhur, seperti jiwa keihklasan, kesederhanaan, kesanggupan menolong diri sendiri, ukhuwah Islamiyah, dan jiwa bebas, adalah ada relevansinya dengan pemikiran al-Ghazali tentang ilmu pendidikan Islam yang menekankan pada pentingnya nilai-nilai luhur yang dapat menenangkan jiwa dan mendekatkan diri kepada Allah serta bermanfaat bagi kemaslahatan umat. Inilah titik temu corak pemikiran para filosof pendidikan Islam yang berangkat dari pandangan yang berbeda-beda dalam tataran konsep, namun mempunyai titik singgung yang sama yaitu teraktualisasinya ilmu pendidikan Islam yang bermanfaat bagi kemaslahatan umat.

Imroatul Fatihah Vol. 2 No.2 ISSN 2549-0877 


\section{Sintesa PMDG}

Sintesa Pondok Modern

Darussalam Gontor (PMDG) tidak lepas dari gagasan dan kepemimpinan $\mathrm{KH}$. Imam Zarkasyi. Sintesa ketiga dari Pondok Modern Gontor adalah Syanggit di Mauritania, Afrika Barat Daya dengan kemampuan mengislamkan Afrika Barat Daya dan memproduksi da'i-da'i yang handal.

Penulis mendapatkan informasi yang cukup menarik dari Prof. Dr. Amal Fathullah Zarkasyi, MA., Rektor UNIDA Gontor, tentang perguruan Syanggit itu bahwa KH. Imam Zarkasyi mendapatkan informasi tentang perguruan itu dari $\mathrm{KH}$. Mas Mansur, seorang tokoh Syarekat Islam dan Muhammadiyah di Indonesia. Menurutnya, Santineketan di India dikenal dengan kedamaian dan kesederhanaannya dari sebuah desa kecil, Rabindranath Tagore sanggup mengajar dunia. Meskipun Santineketan adalah lembaga pendidikan Hindu, tetapi lembaga itu penuh dengan nuansa kedamaian. Meskipun berlokasi di tengah hutan dan jauh dari keramaian, tetapi Santineketan berasrama dan sangat damai. Lembaga ini mampu mengajar dunia dari tengah hutan yang sepi di sana.

KH. Imam Zarkasyi bersama kedua kakaknya ada awal pembangunan Pondok Gontor Baru telah mengkaji berbagai lembaga pendidikan terkenal dan maju di luar negeri, khususnya yang sesuai dengan sistem pondok pesantren. Di Mesir terdapat Universitas al-Azhar yang terkenal dengan keabadiannya. Di Mauritania terdapat Pondok Syanggit. Lembaga pendidikan ini harum namanya berkat kedermawanan dan keikhlasan para pengasuhnya. Syanggit adalah lembaga pendidikan yang dikelola dengan jiwa keikhlasan; para pengasuh mendidik murid-murid siang-malam serta menanggung seluruh kebutuhan santri. Di India terdapat Universitas Muslim Aligarh, sebuah lembaga pendidikan modern yang membekali mahasiswanya dengan ilmu pengetahuan umum dan agama serta memjadi pelopor revival of Islam. Di India juga terdapat perguruan Santiniketan, didirikan oleh Rabindranath Tagore, seorang filosuf Hindu. Perguruan yang dikenal dengan kedamaiannya ini berlokasi di kawasan hutan, serba sederhana dan telah mampu mengajar dunia.

Keempat lembaga pendidikan tersebut menjadi menjadi pedoman dalam mengembangkan Pondok Modern Darussalam Gontor oleh KH. Imam Zarkasyi bersama kedua kakaknya.

KH. Imam Zarkasyi yang lebih dikenal modernis dalam dunia pendidikan Islam menempatkan Gontor bukan hanya sebagai lembaga pendidikan agama, melainkan pendidikan umum yang bernafaskan Islam. Bahasa Arab dan bahasa Inggris menjadi pelajaran penting dan harus dikuasai oleh para santri pada tingkatan tertentu (Misbach, 1996: 596).

Namun demikian, KH. Imam Zarkasyi memiliki pandangan bahwa hal yang terpenting dalam pesantren bukanlah pelajarannya semata-mata, melainkan juga semangat yang menyertainya. Menurutnya, semangat/jiwa itulah yang akan memelihara kelangsungan hidup pesantren dan menemukan filsafat hidup para santrinya. Pada seminar pondok pesantren se-Indonesia tahun 1965 di Yogyakarta, Imam Zarkasyi merumuskan gagasannya berupa Panca Jiwa Pondok Modern. Panca Jiwa Pondok Modern adalah keikhlasan, kesederhanaan, kesanggupan menolong diri sendiri (self help), ukhuwah Islamiyah, dan jiwa bebas.

Gagasan Panca Jiwa Pondok Modern diterapkan dengan sangat baik dan dapat dilihat dari demografi lulusannya. Alumni Gontor memiliki kontribusi pada berbagai bidang pekerjaan, dari politikus (KH. Hidayat Nur Wahid) hingga jurnalis sekaligus novelis (Ahmad Fuadi), namun kebanyakan dari mereka bekerja sebagai 
wirausahawan dan ilmuwan/akademisi, dalam negeri maupun luar negeri. Selain itu, jika dilihat secara substansial, Panca Jiwa Pondok Modern merupakan aplikasi dari pendidikan karakter yang selama ini didengung-dengungkan oleh sekolah umum namun belum menemukan bentuk yang idealnya.

Melalui paragraf-paragraf di atas, terlihat bahwa kepedulian KH. Imam Zarkasyi pada dasarnya tidak sempit; berkisar pada bagaimana melestarikan lembaga pendidikan berformat pesantren. Lebih luas dan visioner dari itu, ia melihat dinamika dunia pendidikan sebagai sebuah solusi esensial perlu diperbarui untuk membentuk moral dan pola pikir secara seimbang, tentunya dalam mainframe keislaman dan scope kehidupan berbangsa dan bernegara, bukan hanya dalam lingkup kesukuan.

Maka, PMDG diposisikannya lebih jauh sebagai media untuk menyebarkan gagasannya mengenai modernitas lembaga pendidikan Islam alih-alih sekedar melestarikannya sebagai sebuah corak pendidikan keislaman tradisional di Indonesia. Lebih luas dan visioner dari itu, ia melihat dinamika dunia pendidikan sebagai sebuah solusi esensial perlu diperbarui untuk membentuk moral dan pola pikir secara seimbang.

Presiden Keenam RI Susilo Bambang Yudoyono membenarkan wujud sintesa yang dilakukan PMDG. Dalam sambutan peringatan 80 tahun Pondok Modern Gontor 28 Mei 2006, Susilo Bambang Yudoyono mengatakan, di PMDG para kyai tidak saja mengajarkan literatur-literatur klasik tentang Islam, tetapi juga menelaah khasanah kepustakaan yang ditulis oleh para mujahid, para pembaharu.

Susilo Bambang Yudoyono melanjutkan, PMDG sangat terbuka dengan wawasan pemikiran modern yang datang dari mana saja. Sebagai lembaga pendidikan yang mempertahankan sebagian tradisi pesantren dan juga mengadopsi kelembagaan pendidikan modern dari luar negeri, maka PMDG mampu memiliki ciri dan karateristik yang khas. Pondok Modern Darussalam Gontor telah berhasil memelihara tradisi lama yang baik serta menerapkan inovasi baru yang sejalan dengan perkembangan jaman.

Tradisi lama dan inovasi baru yang itu terasa lebih memiliki nilai tambah ketika para pimpinan pondok ini berhasil menggabungkan berbagai tradisi pendidikan dari seluruh penjuru dunia. Antara lain tradisi pendidikan dari Universitas Al-Azhar Kairo sebagai salah satu bukti intelektual Islam paling depan. Perguruan Sanggit yang menginspirasi pentingnya beasiswa bagi para santri. Perguruan Santineketan dengan pendekatan kebudayaan dan Perguruan Aligarh yang mengilhami pentingnya pendidikan modern dalam Islam.

Tradisi-tradisi dari berbagai perguruan ini menjadi inspirasi bagi para pengasuh dan kyai yang meletakkan sistem dan metode pendidikan yang khas Pondok Modern Darussalam Gontor. Dengan sistem dan metoda yang khas, pondok ini telah berhasil mencetak kader bangsa yang tangguh, tanggon dan trengginas. Selain itu juga kader umat yang beriman, bertakwa dan berpengetahuan luas.

Tentang masa depan pondok pesantren, KH. Imam Zarkasyi menyatakan bahwa pondok pesantren harus selalu dinamis, mengikuti perkembangan dan tuntutan zaman. Menurutnya, karena zaman selalu berkembang dan maju, maka seharusnya pelajaran dalam pondok pesantren diselenggarakan sesuai dengan masa depan kehidupan para santri di dalam masyarakat. Selain itu, syarat material harus juga dipenuhi, yaitu harus ada wakaf sebagai backing bagi kelangsungan hidup pondok pesantren dan untuk meningkatkan mutu

Imroatul Fatihah Vol. 2 No.2 ISSN 2549-0877 
pendidikan dan pengajarannya. Ini seperti yang terjadi, misalnya, di al-Azhar, Mesir.

Dengan idealisme seperti di atas, KH. Imam Zarkasyi telah melahirkan beberapa tokoh-tokoh Islam di Indonesia. Hal itu ditegaskan oleh Wakil Presiden RI Muhammad Jusuf Kalla ketika membuka acara peringatan 80 tahun ini. Dalam sambutannya, Wakil Presiden RI mengatakan, Pondok pesantren (ponpes) modern Darussalam yang memasuki usia ke-80 tahun ini telah memberikan pendidikan dan pembelajaran yang bermutu bagi kehidupan masyarakat di Indonesia dalam sejarah bangsa. Ponpes ini telah berhasil memunculkan tokoh-tokoh nasional yang banyak berperan dalam proses mencerdaskan bangsa, di antaranya Ketua MPR RI Dr. Hidayat Nur Wahid, Pimpinan Muhammmadiyah Prof. Dr. Din Syamsudin dan Pimpinan Nahdhatul Ulama KH. Hasyim Muzadi.

Tentang sistem pendidikan Islam, Imam Zarkasyi menyatakan bahwa pendidikan dan pengajaran agama lebih tepat dilaksanakan secara klasikal dan bukan individual atau halaqah. Dengan klasikal, para guru--bahkan kiai--dituntut untuk mengetahui apakah santri atau muridnya telah mengerti apa yang diajarkannya atau tidak, karena di akhir pelajaran diharuskan ada evaluasi. Sementara itu, dalam sistem halaqah yang banyak dilakukan di pesantren-pesantren lain pada masa itu, tidak mengharuskan adanya evaluasi di akhir sebuah proses pembelajaran. Padahal, evaluasi merupakan salah satu komponen dari sekian banyak komponen dalam peningkatan kualitas pendidikan dalam Standar Nasional Pendidikan di Indonesia.

Selain itu, dalam pemikiran $\mathrm{KH}$. Imam Zarkasyi Ilmu Mantiq (Logika) dan Filsafat harus diajarkan di pondok pesantren. Sedangkan di pondok pesantren lain ada sekelompok ulama yang menganggap bahwa kedua ilmu tersebut tidak baik untuk diajarkan, bahkan ada yang mengharamkannya. Bukan itu saja, menurut KH. Imam Zarkasyi, di pondok pesantren harus diajarkan ilmu pengetahuan umum, disamping ilmu agama yang memang menjadi core-nya, meskipun sebenarnya, menurut $M$. Din Syamsuddin, sesuai dengan universalitas Islam sendiri, Islam tidak mengenal dikotomi antara ilmu-ilmu agama (al'ulûm al-dîniyyah) dan ilmu-ilmu umum (al-'ulûm al-madaniyyah), tapi memungkinkan pengintegrasian antara keduanya ke dalam suatu paradigma ilmu Islami.

Namun, menurut KH. Imam Zarkasyi, "pelajaran yang diberikan di pondok pesantren tingkat menengah adalah pengetahuan umum dan pengetahuan agama tingkat lanjutan, tetapi setingkat bukan berarti sama." Sementara itu, di banyak pesantren saat itu, hanya diajarkan ilmu-ilmu agama, menganggap Ilmu Manthiq dan Filsafat sebagai kurang baik, bahkan haram diajarkan. Boleh jadi, kelompok pesantren dan ulama yang berpendapat sedemikian itu dipengaruhi oleh pemikiran Syaikh Burhânuddîn al-Zarnujîy, pengarang kitab Ta'lîm al-Muta'allim Tharîq al-Ta'allum, yang merupakan kitab klasik terkenal dan banyak dikaji di pondok pesantren tradisional, khususnya bagi santri pemula. Kitab ini mengandung tata cara belajar ilmu agama dan etika santri kepada kiai dan gurunya.

Ada hal lain yang harus ditekankan dalam pendidikan pondok pesantren dalam pemikiran KH. Imam Zarkasyi, yaitu pentingnya memperhatikan sopan santun dalam hal memuliakan ilmu dan guru, dan akhlak mulia. Yang dimaksud dengan akhlak mulia dalam pandangan Imam Zarkasyi, termasuk belajar dengan sunguhsungguh, tawakkal, asih, menjauhi perbuatan-perbuatan haram, dan sebagainya. Oleh karena itu, motto Imroatul Fatihah Vol. 2 No.2 ISSN 2549-0877 
pendidikan pesantren dalam pemikiran Imam Zarkasyi adalah Berbudi Tinggi, Berbadan Sehat, Berpengetahuan Luas, dan Berpikiran Bebas.

Berbeda dari konsep pendidikan di pesantren-pesantren yang mengadopsi konsep az-Zarnujîy dalam kitab Ta'lîm alMuta'allim, KH. Imam Zarkasyi berpendapat bahwa pesantren tidak perlu menekankan macam makanan yang perlu dimakan oleh santri supaya mudah menghafal dan tidak menjadi pelupa. Namun, di pondok pesantren harus ditekankan perlunya hidup sederhana juga dalam hal makanan. Juga menurutnya, santri tidak perlu melakukan "amalanamalan" yang diharapkan mendatangkan rezeki, tetapi yang perlu adalah usaha dan berjuang secara gigih untuk mendapatkan rezeki itu, dan harus disertai doa. Selain itu, di pondok pesantren harus ada pendidikan rela berkorban, seperti mewakafkan sebagian atau bahkan sebagian besar harta untuk kepentingan pesantren dan umat. Inilah yang saat ini disebut philanthropy atau kedermawanan dalam Islam.

Pesantren yang didirikan $\mathrm{KH}$. Imam Zarkasyi pun tidak berafiliasi kepada partai atau tarekat apapun. Karena tidak mengikuti aliran tarekat atau partai politik tertentu, maka diantara semboyan pondok pesantren yang didirikan KH. Imam Zarkasyi dan kedua kakaknya adalah "Pondok Modern Gontor diatas dan untuk semua golongan". Artinya, pondok pesantren ini tidak dibawah aliran atau golongan tertentu, dan boleh dimasuki oleh siapa saja dan dari golongan apapun.

Amin Abdullah, seorang Guru Besar Universitas Islam Negeri Sunan Kalijaga Yogyakarta dan alumni Gontor menafsirkan bahwa semboyan di atas merupakan tugas yang bersifat kreatif dan orisinal yang dapat diperankan oleh siapa saja yang mempunyai good will sebagai ummatan wasathan atau keperekatan umat. Namun, sebagai perekat umat, alumni pondok pesantren harus bergabung dan berkiprah di dalam berbagai organisasi Islam yang sesuai dengan panggilan hati dan latar belakang masing-masing, dan bukan bermain di luar pagar sehingga tidak dapat berbuat apa-apa, tetapi harus dihindari sikap fanatik yang pekat, yang mencampur-adukkan end dan mean sebuah organisasi.

KH. Abdullah Syukri Zarkasyi juga menegaskan, boleh saja aktif di partai politik, asal sudah menjadi alumni. Menurutnya, pondok pesantren harus netral dari politik. Arah dan tujuan pendidikan dan pengajaran di pondok pesantren, menurut pemikiran KH. Imam Zarkasyi adalah kemasyarakatan, hidup sederhana, tidak berpartai, dan ibadah yaitu thalab al'ilm, bukan menjadi pegawai.

\section{Kaderisasi ala Gontor}

KH. Imam Zarkasyi merupakan salah satu tokoh pendidikan Islam pada abad-20. Ia sangat memberi perhatian terhadap proses kaderasi atau estafeta PMDG untuk tetap langgeng yang bermanfaat bagi umat. Akhirnya, Gontor diakui berpengalaman dan memiliki metode tersendiri untuk mencetak para kadernya dengan berbagai macam trik dan tipsnya. Ini tidak lepas dari kejeniusan dan visionernya $\mathrm{KH}$. Imam Zarkasyi.

Pondok Modern Darussalam Gontor pun dalam mendidik santri-santri sudah memiliki trik ataupun cara tersendiri berdasarkan pengalaman puluhan tahun, hingga kini masuk ke 91 tahun, sudah mendekati satu abad. Pengalaman tersebut menghasilkan beberapat metode yang disebut dengan Metode Kaderisasi Pemimpin. Sedikitnya, ada enam metode yang diterapkan dalam proses kaderisasi para kader-kader terbaiknya, antara lain: pengarahan, pelatihan, penugasan, pembiasaan, pengawalan, pengawalan, uswatun hasanah, dan pendekatan.

Imroatul Fatihah Vol. 2 No.2 ISSN 2549-0877 
Pertama, pengarahan. Dalam proses pembentukan karakter pemimpin, pemberian pengarahan terhadap santri sebelum melaksanakan berbagai kegiatan adalah muthlak bersifar sangat penting. Dengan pengarahan, santri akan diberikan pemahaman terhadap seluruh kegiatan yang akan dilaksanakan, kemudian dievaluasi setelahnya untuk mengetahui standar pelaksanaan kegiatan tersebut.

Maka, dalam setiap kegiatan di Gontor ada pengarahannya seperti, pembukaan tahun ajaran baru, pembagian jadwal guru, pekan perkenalan khutbatul 'arsy, pengarahan ujian, dan kegiatankegiatan lainnya. Pengarahan bertujuan untuk memberikan pemahaman agar santri mengerti untuk apa melaksanakan kegiatan, bagaimana tehnik pelaksanaan, mengapa dan bagaimana pelaksanaan, apa isi dan filosofinya.

Kedua, pelatihan. Pengarahan saja tidak mencukupi, santri harus mendapatkan pelatihan-pelatihan hidup sehingga bisa trampil dalam bersikap dan menyikapi kehidupan ini. Hingga ia memiliki wawasan yang luas, baik wawasan keilmuan, pemikiran, dan pengalaman. Seperti, pelatihan keguruan (untuk guru/ustadz), organisasi di tingkat asrama sampai tingkat pelajar, kursus atau klubklub seni dan olahraga, sampai tingkat mahasiswa pun tetap mendapatkan pelatihan. Dalam pelatihan tersebut di dalamnya terdapat pelatihan kepemimpinan, pelatihan pengorbanan, kesabaran, kesederhanaa, dan pelatihan hidup bersama.

Dinamika pelatihan tesebut sangatlah membentuk dan mewarnai mental dan karakter, karena semakin trampilllan santri, maka semakin tinggilah kepercayaan diri santri. Hal-hal inilah yang mendorong santri Gontor selalu berpartisipasi di manapun berada. Namun demikian, pengarahan dan pelatihan saja tidak cukup, calon pemimpin harus diberi tugas, karena dengan tugas, santri akan terdidik, terkendali dan termotivasi.

Ketiga, penugasan. Penugasan adalah proses penguatan dan pengembangan diri. Maka, barang siapa yang banyak mendapatkan tugas atau melibatkan diri untuk berperan dan menfungsikan dirinya dalam berbagai kegiatan dan tugas, maka dialah yang akan kuat dan trampil dalam menyelesaikan berbagai problema hidup. Dengan begitu santri Gontor dikenal sebagai santri yang dinamis, karena memang tata kehidupan di dalamnya memiliki dinamika dan disiplin yang tinggi serta diberi muatan jiwa ataupun filsafat hidup.

Dalam kamus Gontor, tidak berlaku orang diberi tahu atau dikasih tahu, diberi tugas dan dikasih tugas. Yang berlaku adalah, siapa yang banyak mengambil inisiatif mencari pekerjaan atau tugastugas, dialah yang akan banyak mendapatkan keuntungan. Karena itu, tugas adalah suatu merupakan suatu kehormatan dan kepercayaan sekaligus kesejahteraan. Dia tidak saja akan musta'mal, tetapi juga mu'tabar, mu'tarof bahkan muhtarom. Maka, beruntunglah orang yang mendapatkan tugas-tugas dan mampu menyelesaikannya. Berarti dia terhormat sekaligus terpercaya.

Keempat, pembiasaan. Pembiasaan merupakan unsur penting dalam pengembangan mental dan karakter santri. Pendidikan Gontor adalah pembiasaan. Maka, seluruh tata kehidupan di Gontor seringkali diawali dengan proses pemaksaan. Seperti, sebagian besar santri sulit untuk mengikuti disiplin pondok, disiplin pergi ke masjid. Caranya, dengan memberikan absen sebelum berangkat ke Masjid. Pada awalnya ada unsure keterpaksaan, namun akhirnya santri akan terbiasa untuk berdisiplin.

Kelima, pengawalan. Mengawal seluruh tugas dan kegiatan santri agar selalu mendapatkan bimbingan, sehingga 
seluruh apa yang telah diprogramkan mendapatkan kontrol, evaluasi, dan langsung diketahui. Pengawalan ini sangat penting untuk mendidik, dan memotivasi. Tidak hanya santri, tetapi bagi pengurus instruktur bahkan kyai juga ikut terdidik. Seperti ungkapan, "Guru sebenarnya tidak saja mengajari muridnya, tetapi dia juga mengajari dirinya sendiri."

Keenam, uswatun hasanah atau suri tauladan. Dalam suatu pendidikan, upaya ini menjadi sangat penting dalam keberhasilan pendidikan. Karena Rasulullah SAW beserta para sahabatnya berhasil membina umat dengan memberikan suri tauladan. Maka, proses kaderisasi yang dijalankan oleh pedidikan Gontor sebenarnya proses uswatun hasanah yang selalu diberikan oleh para pendirinya, pimpinan, pengasuh, dan guru. Bahkan pengurus yang ada di pondok ini.

Ketujuh, pendekatan. Keenam metode tersebut belum mencukupi bila tidak disertai dengan pendekatanpendekatan. Ada tiga macam pendekatan menurut Gontor; pertama, pendekatan manusiawi; pendekatan secara fisik dengan cara memanusiakan calon pemimpin. Kedua, pendekatan program; pendekatan tugas ini akan menjadikan calon pemimpin menjadi lebih terampil, bertujuan untuk bertambahnya pengalaman, dan wawasan. Ketiga, pendekatan idealisme; upaya memberikan ruh, ajaran, filosofi di balik penugasan.

Keberhasilan metode pendidikan Gontor membawa para alumninya bergerak diberbagai lini masyarakat seperti, almarhum Dr. KH. Hasyim Muzadi (Anggota Dewan Pertimbangan Presiden, Mantan Ketua Umum PBNU), Dr. Abdurrahman Mohammad Fachir (Wakil Menteri Luar Negeri RI), Abu Bakar Baasyir (Pimpinan Pondok Pesantren Ngruki Solo), Prof. Din Syamsuddin (Mantan Ketua Umum PP Muhammadiyah dan MUI), Adnan Pandu Praja (Mantan
Wakil Ketua Komisi Pemberantasan Korupsi), KH. Ahmad Cholil Ridwan (Mantan Ketua Dewan Dakwah Islamiyyah), Ahmad Fuadi (Jurnalis, Novelis, Peraih Education UK Alumni Award 2016), dan masih banyak para alumni yang tidak bisa disebutkan satupersatu.

Cendekiawan Muslim yang juga Guru Besar Institut Pertanian Bogor (IPB) Prof Dr KH Didin Hafidhuddin mengungkapkan kaderisasi yang berlangsung di Pondok Modern Darussalam Gontor Ponorogo berjalan dengan sangat mulus (Republika.co.id, 21 Februari 2016). Direktur Program Pascasarjana Universitas Ibnu Khaldun (UIKA) Bogor itu pun mengucapkan tahniah dan selamat kepada Pondok Modern Gontor Ponorogo yang kini memasuki usia yang ke-90 tahun pada tahun 2017 lalu.

Ia berharap PMDG akan semakin berkembang tambah kuat, tambah maju, tambah berkah dan semakin bermanfaat bagi penguatan pendidikan kader umat. Kiai Didin menilai para pendiri Pondok Modern Gontor termasuk KH. Imam Zarkasyi adalah figur-figur pendidik yang sesungguhnya yang rela mengorbankan apa pun untuk kemajuan pondoknya. Terbukti, kiprah yang luar biasa dari alumninya yang tersebar dalam berbagai bidang nyata dirasakan oleh umat.

Dalam bidang pendidikan dan dakwah, sambung Tokoh Perbukuan Indonesia ini, ada sosok KH Hasyim Muzadi, Prof Dr KH Dien Syamsuddin, Prof Dr KH Ahmad Satori Ismail dan yang lain-lain, yang terus menerus berbuat untuk kepentingan dakwah dan pendidikan umat. Begitu juga sosok Dr KH Hidayat Nur Wahid, sosok politisi yang santun yang kini memimpin lembaga tinggi negara. Pak Menteri Agama, Lukman Hakim Saifuddin, Pak Fachhir yang menjadi Wakil Menteri Luar Negeri dan yang 
lainnya. Begitu juga juga dalam bidang ekonomi, banyak alumnus Pondok Modern Darussalam Gontor menjadi pengusaha. Hal itu karena proses pendidikan yang berlangsung di PMDG menekankan pada aspek akhlak dan moral, pada kemandirian, kebersamaan dan kemampuan berkomunikasi.

Putra sulung KH. Imam Zarkasyi, Dr. KH. Abdullah Syukri Zarkasyi, MA menjelaskan, Pondok Modern Darussalam Gontor adalah lembaga kaderisasi pemimpin umat. Untuk itu dibentuklah tempat berlatih hidup ideal bagi calon pemimpin umat dengan merangkum berbagai pendekatan. Diantaranya; pendekatan manusiawi, tugas dan idealisme, sehingga memungkinkan kader terlahir (terbentuk) dan terbina pola pikir, sikap dan perilaku sebagai pemimpin (Zarkasyi, 2005).

Sebagai rahim untuk melahirkan kader pemimpin umat, standar pendidikan kepemimpinan di Pondok Gontor dibuat dengan kualifikasi tertentu; serta proses kaderisasi yang dikembangkan juga memiliki ukuran jelas. Terdapat 14 kualifikasi (parameter) dalam kaderisasi kepemimpinan, yaitu: Ikhlas, selalu mengambil inisiatif, mampu membuat jaringan kerja dan memanfaatkannya, dapat dipercaya, bekerja keras dan bersungguh-sungguh, menguasai masalah dan dapat menyelesaikannya, berintegritas tinggi, memiliki nyali tinggi dan tidak takut risiko, jujur dan terbuka, siap berkorban, tegas dan cerdas (dalam melihat, mendengar, mengevaluasi, menilai, memutuskan dan menyelesaikannya setiap masalah), mampu berkomunikasi dan baik dalam bermuamalah.

Gontor dengan sebagai lembaga pendidikan Islam mencetak kader-kader pemimpin umat; menjadi tempat ibadah dan sumber ilmu pengetahuan agama dan umum, dengan tetap berjiwa pesantren.
Mempersiapkan generasi unggul dan berkualitas menuju terbentuknya khaira ummah. Mendidik, mengembangkan generasi mukmin, muslim, berbudi tinggi, berbadan sehat, berpengetahuan luas, berpikiran bebas serta berkhitmad kepada masyarakat. Mengajarkan ilmu agama dan umum secara seimbang (sama besar, masing-masing dalam porsi $100 \%$ ), menuju terlahirnya 'Ulama yang intelek. Mempersiapkan warga negara yang beriman dan bertakwa kepada Allah Swt.

Untuk tujuan terbentuknya pemimpin, kiai bukan hanya me-manage, teach dan lead secara parsial. Malainkan total mendidikkan kehidupan secara utuh dan melibatkan dirinya dengan berbekal iman, ilmu, amal, akhlaq, komunikasi/interaksi dan mental yang tangguh. Sehingga terlahir pemimpin yang harus menguasai permasalahan, selalu banyak mengambil inisiatif, tidak menunggu diperintah, mampu menciptakan pekerjaan dan tidak mencari pekerjaan.

Pondok yang banyak melahirkan pemimpin mulai dari di daerah sampai tingkat nasional ini memiliki motto siap dipimpin dan siap untuk memimpin. Beberapa point penting yang diajarkan KH. Imam Zarkasyi dan para pendiri PMDG adalah berikut ini:

Skill kepemimpinan yang berdasar teori saja tanpa menyertakan jiwa dan filsafat hidup tidak akan banyak artinya. Model kepemimpinan yang didapat dari akademis saja akan menjadi pasif. Lain halnya dengan model kepemimpinan yang didasarkan pengalaman dan merasakan langsung sebagai pemimpin.

Seorang pemimpin harus menyertakan jiwa kejuangan dan pengorbanan serta kesungguhan. hal ini karena orang yang berbicara, menyampaiakan dengan jiwa dan hatinya akan terasa lebih masuk dan memberi atsar yang baik dihati.

Imroatul Fatihah Vol. 2 No.2 ISSN 2549-0877 
Mendidik santri dengan penugasan, santri diberdayakan dan digerakan dengan berbagai macam tugas dan kegiatan merupakan cara untuk mendidik yang baik. Sebagai contoh, ketika ada kunjungan Menteri ke Gontor, maka santri diwajibkan berkumpul di BPPM. Mereka juga terlibat dalam penyambutan tamu tersebut sebagai bagian keamanan misalnya atau pasukan marching band atau penerima tamu ataupunbagian dekorasi yang menyiapkan background di BPPM.. Dalam acara ini santri punya andil dan bekerja. Tata cara penyambutan seperti ini bukan hanya untuk menghormati kedatangan tamu saja, tetapi lebih dari itu adalah untuk mendidik santri. Sasaran yang dituju yaitu menginformasikan kepada santri bagaimana cara menyambut tamu secara baik, inilah sebuah pendidikan bagi santri mengingat banyak hal yang diberayakan, mulai dari santri guru sampai pimpinan juga. Inilah gaya dan cara Gontor dalam rangka mencetak para pemimpinpemimpin masa depan.

Para santri sebagai kader-kader umat sudah dididik memimpin dan hidup dalam lingkungan keorganisasian. Reformasi kepengurusan dalam sebuah keorganisasian dilakukan secara rutin setiap tahunnya. Tanpa adanya regenerasi dan kaderisasi dalam sebuah kepengurusan, maka kepengurusan tersebut tidak akan mengalami perubahan maupun perkembangan baik dalam segi kaderisasi kepengurusannya ataupun sistem dan nilai keorganisasiaannya.

Regenerasi kepengurusan suatu organisasi ini merupakan bentuk kaderisasi. Dalam proses menjalankan kaderisasi dalam suatu organisasi ataupun kepanitiaan dibutuhkan sebuah pengawalan terhadap militansi dan etos kerja kader kader tersebut. Demikian pula halnya Organsasi Pelajar Pondok Modern (OPPM).
Proses pengkaderan pada OPPM terutama dilaksanakan pada Pengurus Harian OPPM dan beberapa bagian tertentu seperti Koperasi Pelajar dan Koperasi Dapur, Bagian Photografi dan Photocopy juga beberapa instansi lainnya.

Pada bagian Pengurus Harian OPPM, bagian Keamanan dengan sengaja memilih siapa diantara siswa kelas 4 dan 5 yang dipercaya mampu untuk menjadi Ketua Rayon maupun Pengurus Rayon kelas 4. Hal ini dimaksudkan agar mempermudah bagian dalam mencari dan menentukan siapa yang akan menggantikan posisinya nanti di Bagian Keamanan ataupun Ketua OPPM itu sendiri.

Proses penyusunan penyusunan struktur kepanitiaan pun memiliki proses yang lama hingga akhirnya dapat diselesaikan dan susunan panitia siap untuk dibacakan oleh Pembimbing Kelas 5 dan Staf Pengasuhan Santri. Kepanitiaan ini akan berlangsung selama lebih kurang lebih tiga pekan. Bukan waktu yang cukup lama, ini merupakan kepanitiaan yang memiliki jangka waktu yang begitu pendek sehingga dibutuhkan kerja keras dan bimbingan penuh dari berbagai pihak, demi mensekseskan acara pergantian Kepengurusan OPPM tahun ini.

\section{Kesimpulan}

KH. Imam Zarkasyi memimpin PMDG dengan uswah hasanah. Karena Kiai merupakan seorang figur yang harus digugu dan ditiru. Hal ini juga sesuai dengan definisi pendidikan yang digagas olehnya bahwa pendidikan ialah apa yang kamu dengar, kamu lihat, dan kamu rasakan. Itulah pendidikan. Namun, uswah hasanah tidak cukup. Miliu atau lingkungan pesantren dibuat sedemikian rupa dalam arti sesibuk mungkin sehingga 
tidak ada waktu santri untuk melakukan pekerjaan yang tidak bermanfaat.

Sebagaimana sabda Nabi SAW, min husni islamil mar'i tarkuhu ma la ya'nihi. Di antara tanda kebaikan keislaman seseorang jika ia meninggalkan hal-hal yang tidak bermanfaat baginya. Alhasil, para santri selalu dalam pengarahan, pelatihan, penugasan, pembiasaan, pengawalan, dan pendekatan. Adagium al-ma'had la yanamu abadan atau pondok tidak pernah tidur terus ditanamkan dalam diri para santri dalam arti bahwa mereka kehidupan mereka di pondok selama 24 jam selalu dalam pengawasan dan perhatian. Hal ini dilakukan untuk menciptakan santri-santri yang mampu menjadi kader umat dan pemimpin di masyarakat kelak. Bukan santri yang berorientasi pegawai, yang ingin dilayani, dan hanya memikirkan perutnya sendiri.

Dengan gaya kepemimpinan $\mathrm{KH}$. Imam Zarkasyi yang memberikan suri tauladan yang baik, visioner, dan penuh keikhlasan lillahi ta'ala wahdah, Pak Zar memiliki pengaruh yang sangat kuat di ingatan, pikiran, dan hati sanubari yang paling dalam para santrinya. Buktinya, santri mampu berjuang dan menularkan nilai-nilai yang telah didapat di Pondok Modern Darussalam Gontor saat mereka kembali hidup dengan masyarakat luas di lingkungannya.

\section{Referensi :}

Ali, Mukti. 1991. Ta'lim al-Muta'allim Cermin Imam Zarkasyi. Gontor: Trimurti Press

Ihsan, Nur Hadi dan Muhammad Akrimul Hakim. 2004. Profil Pondok Modern Darussalam Gontor. Ponorogo: Pondok Modern Darussalam Gontor.
Madjid, Nurcholis. 1997. Bilik-Bilik Pesantren Sebuah Potret Perjalanan. Jakarta: Paramadina.

Nata, Abuddin. 2004. Tokoh-tokoh Pembaharuan Pendidikan Islam di Indonesia. Jakarta: PT Raja Grafindo Persada.

Pondok Modern Darussalam Gontor. 1996. KH. Imam Zarkasyi dari Gontor Merintis Pesantren Modern. Ponorogo: Gontor Press.

Praja, Juhaya S. Filsafat dan Metodologi Ilmu dalam Islam.

Steenbrink, Karel A. 1994. Pesantren, Madrasah, Sekolah: Pendidikan Islam dalam Kurun Modern. Jakarta: LP3ES.

Sukarto, D. A. 1996. Biografi K.H. Imam Zarkasyi: Dari Gontor Merintis Pesantren Modern. Ponorogo: Gontor Press.

Susanto, A. 2009. Pemikiran Pendidikan Islam. Jakarta: Hamzah.

Zarkasyi. Imam. 1997. Serba-serbi Singkat tentang Pondok Modern Darussalam Gontor, untuk Pekan Perkenalan Tingkat Dua. Gontor: Darussalam Press.

Zarkasyi, Abdullah Syukri. 2005. Manajemen Pesantren, Pengalaman Pondok Modern Gontor. Ponorogo: Trimurti Press.

Ziemek, Manfred. 1986. Pesantren Dalam Perubahan Sosial. Jakarta: P3M.

Majalah Gontor edisi Februari 2014.

Majalah Gontor edisi Juni 2014.

Republika.co.id

Ceramah KH. Hasan Abdullah Sahal dalam Pelantikan Pengurus OPPM dan Koordinator Gerakan Pramuka, pada 21 Maret 2013. 